\title{
CHANGING PATTERNS OF SERVICEABILITY OF HEALTHCARE INFRASTRUCTURES: AN INVESTIGATION ON PROPOSED SMART CITIES OF WEST BENGAL
}

\author{
Bikram Prasad \\ Research Scholar (Seacom Skills University,Bolpur, W.B) \\ Mail Id: bikram.prasad004@gmail.com \\ Indrajit Ghosal \\ Asst. Professor (Amity Institute of \\ Information Technology) Amity University, Patna \\ ghosal.m1981@gmail.com
}

\begin{abstract}
Better healthcare service delivery is a pertinent parameter to improve Human development Index of a nation. Better service is indispensable without attaining the basic parameters of health like resource allocation, humanitarian approach along with service equivalents coordinated with proper accountability. In the current scenario of development and implementation of smart city projects, integration of heal thcare service delivery have become a subject of paramount importance. In such a situation, it has become necessary to allot the financial as well human resources in proper constructs of service delivery. This action oriented pro-active approach will help in strengthening the pillars of existing as well as conceived smart city projects. This study is an empirical approach to mine out the dimensions emerged due to changing patterns of healthcare service delivery in proposed smart cities of West Bengal. The investigation has explored the parameters of service delivery among the respondents of proposed smart cities. The factors explored are amenability, trustworthiness, competency of the staff, and clinical competency along with timeliness. The findings will act as a value addition for the investors, stakeholders like Public institutions, private organizations, PPP organizations to integrate the strategies of healthcare service delivery with smart city projects effectively. The extracted parameters will also help in designing the serviceability of healthcare infrastructures of smart cities in resilient and sustainableway.
\end{abstract}

Keywords: Smart City, Infrastructure, Healthcare, Service Delivery, Patient Satisfaction, Factor Preferences 
Prestige International Journal of Management \& IT-Sanchayan, Vol. 8 (2), 2019, pp. 57-70, ISSN : 2277-1689 (Print), 2278 - 8441 (Online)

\section{INTRODUCTION}

The developing world's human development and movement landscapes have been characterized by the urbanization (Watson, 2009). Due to urbanization, large number of people move from one part to another city (Hove and Trimboi, 2011). By 2030 , it have been expected that more than $60 \%$ of the world's population will reside in cities as compared to mere $30 \%$ in the era of 1960.But the overwhelming population increase of the urban cities is associated with the unplanned service delivery.

As a result of this there has been rise of social ills like overcrowding, crime, and bred of social ills, lack of sanitation, waste dispose which is often transposed to the planned sections of the society. This has created an infrastructural gap which is creating hindrance in smooth service delivery. The resulting disruption of the service delivery in the unplanned urbanization have necessitate the need of assessing and extracting newly evolved service delivery patterns in healthcare organizations. . Healthcare being one of the standard criteria have been clubbed by the following indicators like Number of Inpatient hospital beds, physicians, nursing personnel per 100,000 populations, Average Life Expectancy, Under Age 5 mortality per 1000 live births, Suicide rate per 100k populations, and mental health population per 100k populations. Hence it is very much necessary to know the gap in infrastructural development based on the transition of service delivery patterns in the healthcare organizations of the smart cities so that they can be used as a inferential guide for addressing the infrastructural gaps in the healthcare industry in the newly evolved landscape of smart cities.

\section{CONCEPT OF SMART CITY}

Infrastructure development in the smart cities is gaining a wide consideration in the existing literature and summits for framing international policies (Albino et al. 2015; Koo et al. 2017; Mori and Christodoulou 2012). In this regard, smart city can be defined as a region which uses advanced and modern technology in order to accomplish daily activity. It uses intellectual ability along with modern computing techniques and algorithm to deal with various social, technical, economical aspects of the development which will ultimately led to the growth modern and superior infrastructure. (Bakıc1 et al. 2013; Cruz-Jesus et al. 2017; Washburn et al. 2010; Zygiaris 2013; Chatterjee and Kar 2018b). According to the reports of the United Nations Population Fund, a majority of population will migrate to cities by 2050(UNFPA 2008). Similarly in Emerging Market Economy(EMEs) like India, large section of rural population is shifting to the city regions due to transition in urbanisation due to emerging "pull factors" like employment opportunity, better standard of living.an sense of security. This has led the reports that Urban areas expected to house $40 \%$ of Indian population and contribute $75 \%$ of India's GDP by 2030. The reports by Mckinsey in 2018 have predicted that by the next 15 years of 
Changing Patterns of Serviceability of Healthcare Infrastructures: An Investigation on Proposed Smart Cities Of West Bengal

this century, 200 million people have transitioned from rural to urban areas in India. This changing patterns of the urbanisation is similar to patterns observed in other nations and is nearly combined to the population of like France, the United Kingdom, and Germany. In this regard, the Government of India have taken steps for integrated, comprehensive and inclusive development in urban areas. The forefront of the development should be on the physical infrastructure, institutional, social and economic infrastructure. The conceptualisation and genesis of smart city is a step forward in such direction in order to accomplish the vicious cycle of growth and development. The Smart Cities Mission is launched by the Government of India in order to provide better service delivery of basic amenities embedded with superior infrastructure, information technology, digital technology, public private partnership, and drafting new policies.

\section{Priori evaluation of proposed smart cities in West Bengal}

Four towns of West Bengal have been proposed. The four proposed cities are Durgapur, Haldia, Bidhannagar and Rajarhat, New Town, Durgapur. New Town is a fast growing planned satellite city of North 24 parganas district of West Bengal. The administrative regulation is controlled by New Town Kolkata Development Authority .It regulates the functions like maintenance of water supply, maintenance of drainage and sewerage, maintenance of road, street lights and waste disposal. The area mainly consists of huge acres of cultivated land which are acquired by the investors in a planned manner. Under the federal system of Indian central government and state government of west Bengal, new town is being proposed as smart green city.

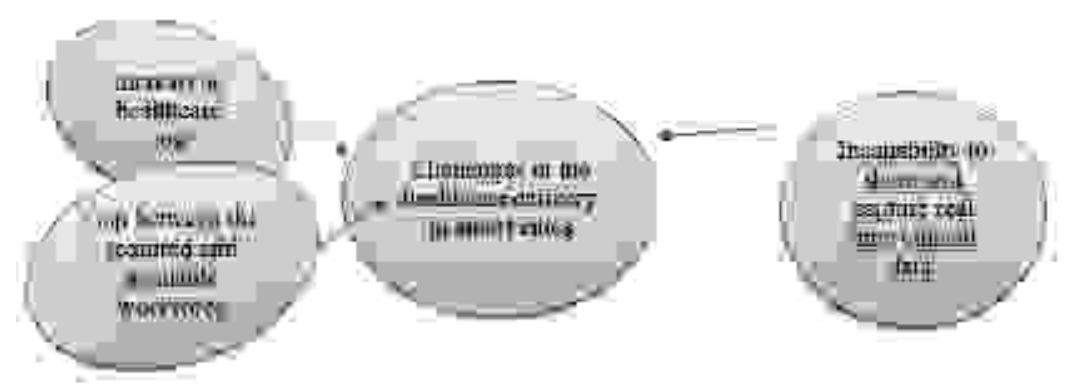

Fig 1: Framework of challenges faced by the smart cities in achieving healthcare targets

Increase in healthcare costs: Privatisation in healthcare have drastically increased healthcare costs. This creates barriers for developing nations like India to achieve universal health coverage. According to Sharma et al.2017,the universal health coverage in turns require regulation of Out-of pocket payments(OOP) as well FRP(Financial Risk Protection).According to the reports of the $\mathrm{WHO}$, about $60 \%$ of 
Prestige International Journal of Management \& IT-Sanchayan, Vol. 8 (2), 2019, pp. 57-70, ISSN : 2277-1689 (Print), 2278 - 8441 (Online)

the healthcare expenditure belongs to the Out-Of Pocket payment category which have led to the growth of the volume of catastrophic healthcare expenditure(CHE).This escalating healthcare expenditure have led to the increase of the sections of the population below poverty line due to increased OOP expenses.

\section{Gap between the required and available workforce}

The availability of adequate manpower is the major concern for the organisational stakeholders, investors and policy makers (Kabene et al, 2006). Adequacy of the health workers is inevitable for the sustainable development for any organisation. Without adequate human resource, the service delivery of the organisation will not achieve consumer satisfaction. As a result in absence of this, the achievement of the Local and National health goals cannot be accomplished without having proper technical and social foundations (Frenk, Sepúlveda, Dantés and Knaul, 2003). According to WHO reports, in India, there is dearth of sufficient number of Human Resources to meet the growing demand of the healthcare service delivery though India have expanded the volume of workforce after the launch of National Health Mission.(Tiwarin, Neganidhi, Zodpey, 2018). Through the recent years, the number of training institutes have grown substantially due to increase in the number of training institutes for doctors, nurses, and healthcare workers. Through National Rural Health Mission, the number of the Accredited Social Health Activist (ASHA) have been expanded to 870089.Besides these, the National health Mission have also created the need for the growth of the HMP (Health Management Professionals). Sharma et al., opined that trained health management professionals are required for smooth execution of healthcare delivery as they work in hospitals, pharmaceutical companies, and health insurance organisations. They adopt customised strategy according to the real time condition to suit according to the multi-professional mode based on multiagency environment and multispectral platform.

\section{Incapability to share and capture real time clinical data}

Healthcare technology and it's extant delivery play a vital role in the healthcare system in the smart cities. This can be achieved fruitfully by incorporating the Information and communication technology(ICT) and Internet of Things(IOT). The Internet of Things(IOT) consist of following pillars like Big data ,mining, cloud, social and robotics and Artificial Intelligence(AI).Due to such advanced technology, real time monitoring of clinical data can be done along with the sharing of relevant data among its stakeholders (clinical research organizations, research groups, R\&D department of the pharmaceutical companies). The feedback captured from the web-connected medical device and clinical observations and databases extracted from such observations help in effective accomplishing of the on-going projects and trials. System has focussed on the collection of KPI to excess and implement the healthcare programmes in future course of action. 


\section{RATIONALE OF THE RESEARCH}

In contemporary scenario, the changing concepts of urbanization have emphasized the need of delivering the proper service in case of basic constructs of life like water supply, waste disposal, maintenance of roads, maintenance of street lights, community parks along with healthcare service delivery. Among these factors, there is increasing need of designing service delivery according to contemporary concepts of the urbanization and smart cities. In such cases, there is need of synchronization of service delivery dimensions based on the changing scenario of urbanization and smart cities. In such cases, understanding of perception of the patients about service delivery is inevitable for effective completion of the study. Existing researches (Taner and Antony, 2006) have also inferred the need of measuring and conceptualizing service quality dimensions in the healthcare organizations. In the healthcare organisations, the choice of the service provider is influenced by the perception of the patients. (Woodside et al., 1989).Thus the healthcare organizations must achieve "zero defections" in order to achieve the patient satisfaction level (Reichheld and Sasser, 1990). According to Lim and Tang (2000) in order to achieve the "zero defect", continuous improvement focussed on the improvement of service delivery is required. In such aspect, it is very much necessary to measure the device quality as it is having elusive and distinctive construct. The parameters like intangibility, inseparability, variability is unique to the service delivery (Zeithaml et al., 1990). Hence, in these present conditions, it is very important to frame the key constructs of the service delivery patterns of the healthcare organisations according to the framework and designs of proposed smart cities. This research will helps in priori analysis of the key parameters of the transition of the service delivery patterns as perceived by the patients and residents of the cities. This priori assessment of the perception will be a guide to the investors, government bodies; nodal policy makers related to healthcare to draft and laid emphasis on the extracted factors.

\section{RESEARCH OBJECTIVE}

The specific objective that we intend to meet

(i) To identify factors affecting the perception towards the service quality of the healthcare organizations.

(ii) To identify the variables which directly affect the satisfaction level of the patients.

\section{RESEARCH METHODOLOGY}

The research is partly descriptive and partly analytical. Data was collected among the patients of the proposed smart cities. To collect data, a structured questionnaire was distributed among the respondents without any discrimination among the 
Prestige International Journal of Management \& IT-Sanchayan, Vol. 8 (2), 2019, pp. 57-70, ISSN : 2277-1689 (Print), 2278 - 8441 (Online)

male and female respondents. A non-probability judgemental sampling has been implemented in the study. The questionnaire was translated and translated back to preserve the semantic consistency between the Bengali and the English Language. Modification of generic instrument of SERVQUAL (Parasuraman et al., 1988) has been adopted while framing the questionnaire. Proper measure of the validity have been done by performing apparent validity, construct validity, convergent validity, content validity, Representation validity, Face validity, criterion validity, concurrent validity and predictive validity. The data was collected among the hospitals of the smart cities through convenient sampling. A total of 100 questionnaires were selected among the 120 distributed questionnaires. The data collected through Self-administered questionnaire. Self-administered questionnaire is the survey in which respondent's takes responsibility of reading and answering the question. It is considered as superior mode for minimizing the bias and improving response rates. Secondary information have been collected from different secondary sources such as books, magazines, journals, and internet databases.

The questionnaire was subjected to statistical control and progressed through reliability and validity test. The factors affecting service quality of the healthcare have been extracted through - variables through data redundancy techniques and Factor analysis. The multiple regression analysis have been used to test the relationship between the independent variable and dependent variable. Bivariate correlation has been used to determine the relationship between the level of satisfaction of the patient and frequency of the visit of the patients to the hospital.

\section{FINDINGS AND DATA ANALYSIS}

The data obtained through questionnaire as subjected to data cleaning in order to identify missing value, data redundancy, sample characteristics and meet the assumptions of normality.

\section{Reliability test on 24 variables}

\begin{tabular}{|l|l|l|}
\hline \multicolumn{3}{|l|}{ Reliability Statistics } \\
\hline $\begin{array}{l}\text { Cronbach's } \\
\text { Alpha }\end{array}$ & $\begin{array}{l}\text { Cronbach'sAlpha Based on } \\
\text { Standardized Items }\end{array}$ & N of Items \\
\hline .883 & .890 & 24 \\
\hline
\end{tabular}

\section{Rotated Component Matrix}

This component matrix sometimes stated to as the loadings, is the key output of principal components analysis. Matrix contains estimates of the correlations between each of the variables and the expected components. 
Changing Patterns of Serviceability of Healthcare Infrastructures: An Investigation on Proposed Smart Cities Of West Bengal

\begin{tabular}{|c|c|c|c|c|c|c|}
\hline \multicolumn{7}{|c|}{ Rotated Component Matrix ${ }^{a}$} \\
\hline & \multicolumn{6}{|c|}{ Component } \\
\hline & 1 & 2 & 3 & 4 & 5 & 6 \\
\hline $\begin{array}{l}\text { This hospital has modern looking } \\
\text { Equipment }\end{array}$ & -.087 & .215 & .152 & -.869 & .128 & .065 \\
\hline $\begin{array}{l}\text { The physical facilities of hospital like } \\
\text { infrastructural facility ,interiors are } \\
\text { visually attractive and pleasant. }\end{array}$ & -.113 & .864 & .015 & -.282 & .074 & .174 \\
\hline $\begin{array}{l}\text { The front desk employees of the } \\
\text { hospital are well groomed }\end{array}$ & .567 & .324 & .597 & .127 & .140 & -.039 \\
\hline $\begin{array}{l}\text { The materials used by the hospital } \\
\text { employees while giving service are } \\
\text { attractive and pleasant. }\end{array}$ & .387 & .333 & .710 & -.070 & -.254 & .247 \\
\hline $\begin{array}{l}\text { The working hours in hospital are in } \\
\text { accordance to my convenience }\end{array}$ & .129 & .079 & .091 & .206 & .511 & .912 \\
\hline $\begin{array}{l}\text { The hospital delivers it's service } \\
\text { within promised and assured time }\end{array}$ & .440 & .417 & .011 & -.488 & -.008 & -.329 \\
\hline $\begin{array}{l}\text { Whenever I face any difficulty, the } \\
\text { hospital takes action with earnest } \\
\text { efforts in solving that }\end{array}$ & .705 & -.249 & .189 & -.474 & .003 & -.149 \\
\hline $\begin{array}{l}\text { This hospital performs the service } \\
\text { rightly since your arrival from the } \\
\text { beginning. }\end{array}$ & .332 & .252 & .837 & -.032 & -.046 & .182 \\
\hline $\begin{array}{l}\text { The hospital delivers it's service } \\
\text { within it's specified promised time. }\end{array}$ & .771 & -.128 & .332 & .111 & .211 & .124 \\
\hline $\begin{array}{l}\text { The employees of this hospital can say } \\
\text { accurately when the service will be } \\
\text { delivered and accomplished. }\end{array}$ & .302 & -.374 & .157 & -.114 & .657 & .300 \\
\hline $\begin{array}{l}\text { The waiting time to see doctor in this } \\
\text { hospital is reasonable and justified. }\end{array}$ & .196 & .016 & .325 & .043 & .874 & -.078 \\
\hline $\begin{array}{l}\text { The employees of this hospital delivers } \\
\text { service in prompt manner. }\end{array}$ & .478 & .506 & .078 & -.257 & .024 & .449 \\
\hline $\begin{array}{l}\text { The employees of this hospital are } \\
\text { always ready and willing to help you }\end{array}$ & .541 & .189 & .094 & .448 & -.067 & -.501 \\
\hline $\begin{array}{l}\text { In spite of having tough schedule and } \\
\text { work load, the employess of this } \\
\text { hospital are never too busy to respond } \\
\text { to }\end{array}$ & -.021 & .073 & .803 & .012 & .219 & -.081 \\
\hline $\begin{array}{l}\text { The employees of this hospital are well } \\
\text { behaved and courteous with me. }\end{array}$ & .738 & .484 & .159 & .218 & -.010 & -.041 \\
\hline $\begin{array}{l}\text { The behavior of employees of this } \\
\text { hospital gives a sense of confidence in } \\
\text { you. }\end{array}$ & .459 & .546 & .300 & -.044 & -.403 & .260 \\
\hline $\begin{array}{l}\text { I feel safe while opting for healthcare } \\
\text { facilities in this hospital. }\end{array}$ & .205 & .787 & .235 & .272 & -.013 & -.264 \\
\hline
\end{tabular}


Prestige International Journal of Management \& IT-Sanchayan, Vol. 8 (2), 2019, pp. 57-70, ISSN : 2277-1689 (Print) 2278 - 8441 (Online)

\begin{tabular}{|l|c|c|c|c|c|c|}
\hline $\begin{array}{l}\text { The employees of this hospital have } \\
\text { sufficient knowledge and skills to } \\
\text { solve my queries. }\end{array}$ & .065 & .057 & .771 & .055 & .360 & -.039 \\
\hline $\begin{array}{l}\text { The doctors of this hospital rightl } \\
\text { explain about my health issues or } \\
\text { condition }\end{array}$ & .103 & .295 & .005 & .886 & .218 & .132 \\
\hline $\begin{array}{l}\text { The doctors of this hospital gives me } \\
\text { exact information about my treatment } \\
\text { status and medications. }\end{array}$ & .202 & -.192 & .249 & .872 & -.014 & .035 \\
\hline $\begin{array}{l}\text { This hospital gives me personalized } \\
\text { attention and importance. }\end{array}$ & .700 & -.283 & .522 & .011 & -.095 & .283 \\
\hline $\begin{array}{l}\text { The employees of this hospital realize } \\
\text { my specific needs }\end{array}$ & .896 & -.010 & .029 & .211 & .197 & .145 \\
\hline $\begin{array}{l}\text { Doctors of this hospital behave with } \\
\text { friendly and helpful manner with me. }\end{array}$ & -.066 & .878 & .287 & -.058 & -.200 & .026 \\
\hline $\begin{array}{l}\text { Doctors of this hospital gives enough } \\
\text { consultation time to tell me what I } \\
\text { need to know and answer my }\end{array}$ & .726 & .382 & .000 & .251 & .394 & -.040 \\
\hline $\begin{array}{l}\text { Extraction Method: Principal Component Analysis. } \\
\text { Rotation Method: Varimax with Kaiser Normalization. }\end{array}$ & & & & & \\
\hline a. Rotation converged in 13 iterations. & & & & & \\
\hline
\end{tabular}

The result from the objec tive is tabulated as follows:

\begin{tabular}{|l|l|}
\hline Serial Number & Statement of factors \\
\hline $\mathbf{1}$ & Amenability \\
\hline $\mathbf{2}$ & Trustworthiness \\
\hline $\mathbf{3}$ & Competency of the staff \\
\hline $\mathbf{4}$ & Clinical facility \\
\hline $\mathbf{5}$ & Timeliness \\
\hline
\end{tabular}

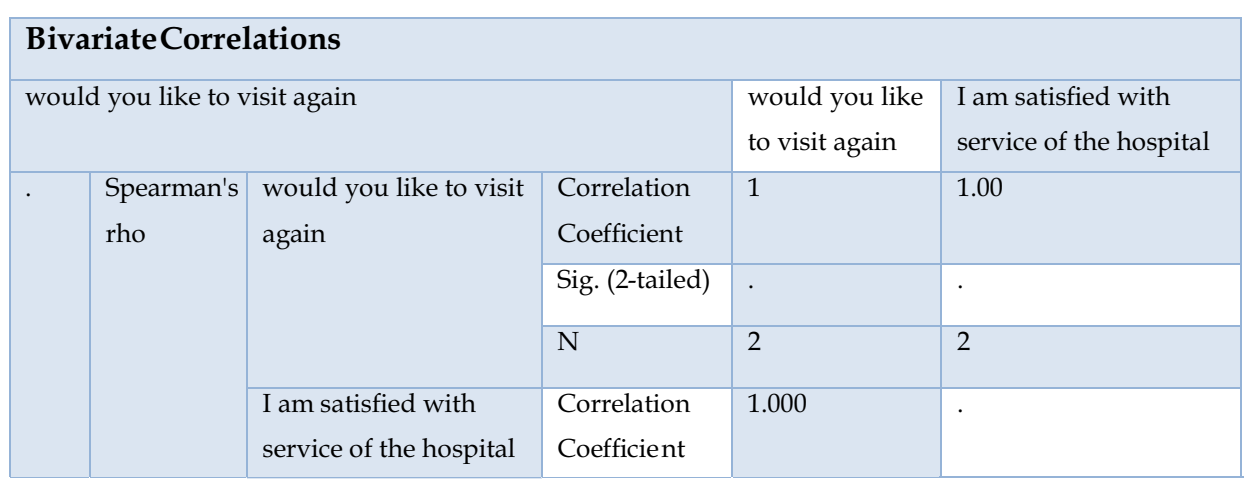


Changing Patterns of Serviceability of Healthcare Infrastructures: An Investigation on Proposed Smart Cities Of West Bengal

\begin{tabular}{|c|c|c|c|c|c|}
\hline & & & Sig. (2-tailed) & . & . \\
\hline & & & $\mathrm{N}$ & 2 & 2 \\
\hline \multirow[t]{6}{*}{ yes } & \multirow[t]{6}{*}{$\begin{array}{l}\text { Spearman's } \\
\text { rho }\end{array}$} & \multirow[t]{3}{*}{$\begin{array}{l}\text { would you like to visit } \\
\text { again and refer }\end{array}$} & $\begin{array}{l}\text { Correlation } \\
\text { Coefficient }\end{array}$ & 1 & .418 \\
\hline & & & Sig. (2-tailed) & . & .000 \\
\hline & & & $\mathrm{N}$ & 73 & 73 \\
\hline & & \multirow[t]{3}{*}{$\begin{array}{l}\text { I am satisfied with } \\
\text { service of the hospital }\end{array}$} & $\begin{array}{l}\text { Correlation } \\
\text { Coefficient }\end{array}$ & . & 1.000 \\
\hline & & & Sig. (2-tailed) & . & . \\
\hline & & & $\mathrm{N}$ & 73 & 73 \\
\hline \multirow[t]{6}{*}{ No } & \multirow[t]{6}{*}{$\begin{array}{l}\text { Spearman's } \\
\text { rho }\end{array}$} & \multirow{3}{*}{$\begin{array}{l}\text { would you like to visit } \\
\text { again } \\
\text { and refer }\end{array}$} & $\begin{array}{l}\text { Correlation } \\
\text { Coefficient }\end{array}$ & 1. & .502 \\
\hline & & & Sig. (2-tailed) & . & .000 \\
\hline & & & $\mathrm{N}$ & 48 & 48 \\
\hline & & \multirow[t]{3}{*}{$\begin{array}{l}\text { I am satisfied with } \\
\text { service of the hospital }\end{array}$} & $\begin{array}{l}\text { Correlation } \\
\text { Coefficient }\end{array}$ & 502. & 1 \\
\hline & & & Sig. (2-tailed) & 000 & . \\
\hline & & & $\mathrm{N}$ & 48 & 48 \\
\hline
\end{tabular}

\section{Regression Analysis}

\begin{tabular}{|c|c|c|c|c|c|c|c|c|c|}
\hline \multicolumn{10}{|c|}{ Model Summary } \\
\hline \multirow[t]{2}{*}{ Model } & \multirow[t]{2}{*}{$\mathrm{R}$} & \multirow{2}{*}{$\begin{array}{l}\mathrm{R} \\
\text { Square }\end{array}$} & \multirow{2}{*}{$\begin{array}{l}\text { Adjusted } \\
\text { R Square }\end{array}$} & \multirow{2}{*}{$\begin{array}{l}\text { Std. Error } \\
\text { of the } \\
\text { Estimate }\end{array}$} & \multicolumn{5}{|c|}{ Change Statistics } \\
\hline & & & & & $\begin{array}{c}\text { R } \\
\text { Square } \\
\text { Change }\end{array}$ & $\begin{array}{c}\text { F } \\
\text { Change }\end{array}$ & df1 & df2 & $\begin{array}{l}\text { Sig. F } \\
\text { Change }\end{array}$ \\
\hline 1 & $.214^{\mathrm{a}}$ & .046 & .036 & 1.15783 & .046 & 4.681 & 1 & 98 & .033 \\
\hline 2 & $.293^{\mathrm{b}}$ & .086 & .067 & 1.13910 & .040 & 4.249 & 1 & 97 & .042 \\
\hline \multicolumn{10}{|c|}{$\begin{array}{l}\text { a. Predictors: (Constant), The employees of this hospital can say accurately when the service will be delivered } \\
\text { and accomplished. }\end{array}$} \\
\hline \multicolumn{10}{|c|}{$\begin{array}{l}\text { b. Predictors: (Constant), The employees of this hospital can say accurately when the service will be delivered } \\
\text { andaccomplished., The doctors of this hospital rightl explain about my health issues or condition }\end{array}$} \\
\hline
\end{tabular}


Prestige International Journal of Management \& IT-Sanchayan, Vol. 8 (2), 2019, pp. 57-70, ISSN : 2277-1689 (Print), 2278 - 8441 (Online)

\begin{tabular}{|c|c|c|c|c|c|c|}
\hline \multirow{2}{*}{\multicolumn{2}{|c|}{ Model }} & \multicolumn{2}{|c|}{$\begin{array}{l}\text { Unstandardized } \\
\text { Coefficients }\end{array}$} & \multirow{3}{*}{$\begin{array}{l}\text { Standardized } \\
\text { Coefficients } \\
\text { Beta }\end{array}$} & \multirow[t]{2}{*}{$\mathrm{t}$} & \multirow[t]{2}{*}{ Sig. } \\
\hline & & B & $\begin{array}{l}\text { Std. } \\
\text { Error }\end{array}$ & & & \\
\hline \multirow[t]{2}{*}{1} & (Constant) & 7.914 & .473 & & 16.735 & .000 \\
\hline & $\begin{array}{l}\text { The employees of this hospital can say } \\
\text { accurately when the service will be } \\
\text { delivered and accomplished. }\end{array}$ & .445 & .206 & .214 & -2.164 & .033 \\
\hline \multirow[t]{3}{*}{2} & (Constant) & 7.340 & .542 & & 13.537 & .000 \\
\hline & $\begin{array}{l}\text { The employees of this hospital can say } \\
\text { accurately when the service will be } \\
\text { delivered and accomplished. }\end{array}$ & .457 & .202 & .219 & 2.259 & .026 \\
\hline & $\begin{array}{l}\text { The doctors of this hospital rightl } \\
\text { explain about my health issues or } \\
\text { condition }\end{array}$ & .296 & .144 & .200 & 2.061 & .042 \\
\hline
\end{tabular}

\section{Regression Analysis}

The results of the regression is given as follows

Patient Satisfaction $=$ PS

$\mathrm{PS}=\mathrm{a}+\mathrm{b}_{10} \mathrm{x}_{10}+\mathrm{b}_{19} \mathrm{x}_{19}$ (As extracted after regression).

$X_{10}=$ The employees of this hospital can say accurately when the service will be delivered and accomplished.

$X_{19}=$ The doctors of this hospital rightl explain about my health issues or condition

$\mathrm{PS}=7.340+.457 \times 10+.296 \times 19$

S.E $=(.542)(.202)(.144)$

T Values $=(13.537)(-2.259)(.200)$

R square(Adjusted) $=0.067$

Significance at $99 \%$

\section{DISCUSSION OF THE FINDINGS}

The data analysed through rotated component matrix have been analysed through rotated component matrix and factors like amenability, trustworthiness, competency of the staff, clinical facility and timeliness of the staff have been obtained. The factors like amenability is defined by the variables like grooming of the employees, earnest efforts taken by the hospital in solving the problems of the hospital, delivering the service with in promised time.

It is encapsulated by other variables like courteous nature with personalized attention, consultation time provided by the doctors. Similarly the factor 
Changing Patterns of Serviceability of Healthcare Infrastructures: An Investigation on Proposed Smart Cities Of West Bengal

trustworthiness has been encapsulated by the factors like behaviour of the employees which instils a sense of confidence among the patient. Feelings of being safe while receiving treatment and friendly behaviour of the employees alters the satisfaction level.

Competency of the employees is the third factor which is clubbed by the third factor which is clubbed by aspects like delivering the right clinical service to the patients, skill and knowledge of the employees in solving the queries in right way. The fourth factor is the clinical facility which is canopied by the capability of the doctors to explain the health issues. It is justified more by the variable like delivering information of treatment status and medication.

In regression analysis, F-test indicate whether the regression model is better fitted into the data as compared to the data which contains no independent variables. Analysis of regression coefficients explain about the relationship between the dependent variable and each independent variable. Thus in this calculation, it is better observed that F-test of regression analysis fits in with the other regression statistics. While hypothesis formulation, intercept only model have also been used that refers the model without any independent variables.

The F-test for overall significance has the following two hypotheses:

$\mathbf{H}_{0}$ : The null hypothesis indicates that the model fits the data with no independent variables.

$\mathbf{H}_{1}$ : The alternative hypothesis indicates that the model fits the data better then the intercept-only model.

In the statistical output, the value of $R$ square is equal to 0.067 which is near equal to $6.7 \%$ i.e patient satisfaction can be explained by the attitude of the employees to say accurately when the service will be delivered and ability of the doctors to rightly explain about the health issues or conditions. The significant F-value of 0.33 rightly indicates that $\mathrm{H}_{0}$ is rejected and $\mathrm{H}_{1}$ is accepted. Thus the model has good fit.

\section{CONCLUSION}

The study is an explorative and inferential guide for the urban planning. The study haver investigated the correlation between the design and parameters of the smart cities with the transition and assessment of the newly evolving service delivery parameters in healthcare organisation, The perception of the patients in such cities have been taken for this purpose in non-contrived settings.

The extracted parameters will help the designers, urban planners, infrastructure engineers, private and public stake holders in allocating the financial resources to 
Prestige International Journal of Management \& IT-Sanchayan, Vol. 8 (2), 2019, pp. 57-70, ISSN : 2277-1689 (Print), 2278 - 8441 (Online)

the proper infrastructural requirements in the healthcare industry. As contemporarily, the policy of the investment in the infrastructural development has been tightened.

Along with that a s the part of the Maximizing Financing for Development(MFD) strategy, the emphasis have been laid on the reduction of dependency of the public funds(i.e. tax payers money) for short term and long term investment. In such a situation India being part of the Emerging Market Economy (EMEs), it is very important to know the service delivery patterns required in the smart cities so that infrastructure gap with proper resource (financial, strategic and manpower) can be conceptualised, designed and addressed.

The study has justified such requirements for the development of smart cities the factors extracted can properly be used by the healthcare organizations to frame their strategies. The strategies based on this frame work can be utilized to frame and incorporate it in service quality policy and procedures for sustainable development of the healthcare organization.

Besides these, the study is a value addition in order to attract the private investors and leveraging the fund from them and thus reducing the infrastructural gaps in the healthcare industry by addressing the parameters as extracted from the study.

\section{LIMITATIONS OF THE RESEARCH}

The research has been conducted on the smart cities of the West Bengal. This study can be extended to wider geography so that deeper analysis of the infrastructure development of the smart cities with respect to healthcare industry can be done. The demographic analysis can be done in order to address the varied cognition among the patients with respect to service delivery patterns.

\section{ACKNOWLEDGEMENT}

This research was supported by the Seacom Skills University Bolpur, West Bengal We would like to thanks the officials of the Seacom Skills University Bolpur West Bengal for giving support and administrative as well as technical assistance. We would like to show gratitude to Professors from Amity University Patna Campus for providing guidance while accomplishing this research work.

We would also like to thank the authorities of the New Town Kolkata Development Authority West Bengal for providing insights on the urbanisation and smart cities. 


\section{REFERENCES}

- Donabedian, A. (1982). Explorations in quality assessment and monitoring: The criteria and standards of quality, 2. MI: Health Administration Press

- Donabedian, A. (1982). Explorations in quality assessment and monitoring: The criteria and standards of quality, 2. MI: Health Administration PressHarrington, L., \& Pigman, H. (2008). “Quality Measurement. In Prathibha.

- Cadotte, Earnest R., Woodruff, Robert B., \& Jenkins, Roger L. (1987) Expectations and Norms in Models of Consumer Satisfaction. Journal of Marketing Research 24: 305-14.

- Parasuraman, A., Zeithaml, V.A. and Berry, L.L. (1988), "SERVQUAL:A MultipleItem Scale for Measuring Customer Perceptions of Service Quality," Journal of Retailing, 64 (Spring), 12-40.

- Woodside, A.G., \& Shinn, R. (1988). Consumer awareness and preference toward competing hospital services. Journal of Health Care Marketing, 8(1), 39-47.

- Tarlov, A. R., Ware, J. E., Greenfeld, S., Nelson, E. C.,Perrin, E., \& Zubkof,M. (1989). The medical outcomes study: An application of methods for monitoring the results of medical care. JAMA, 262,925-930.

- Stefen, G. E. (1988). Quality medical care: A definition. JAMA, 260, 56-61.

- Brown, S.W., \& Swartz, Teresa A. A. (1989). Gap Analysis of Professional Service Quality. Journal of Marketing, 53 (2), 92-98.

- Reidenbach, R.E. and Sandier-Smallwood, B. (1990), Exploring Perceptions of Hospital Operations by a Modified SERVQUAL Approach, Journal of Health Care Marketing, 10 (December), 47-55

- Wiggers, John H., Kathleen O, Donovan., Selina Redman., \& Rob W,Sanson- Fisher. (1990). Cancer Patient Satisfaction with Care. Cancer, 66, 610-616.

- Babakus, E. and Mangold, W.G. (1992), Adapting the SERVQUAL Scale to Hospital Services: An Empirical Investigation, Health Services Research, 26(6), 676-686.

- Babakus, E. and Mangold, W.G. (1992), Adapting the SERVQUAL Scale to Hospital Services: An Empirical Investigation, Health Services Research, 26(6), 676-686.

- Bowers, M.R., \& Swan, J.E., Koehler, W. (1994). “What attributes determinequality and satisfaction with health care delivery?" Health Care Management Review, 19 (4), 49-55.

- Scardina, S. (1994). "SERVQUAL: A tool for evaluating patient satisfaction with nursing care". Journal of Nursing Care Quality, 8, 38-46.

- Cronin, JJ \& Taylor, SA 1994, SERVPERF versus SERVQUAL:Reconciling Performance-Based and Perceptions-Minus- Expectations Measurement of Service Quality', Journal of Marketing, 58, no.1,125-131.

- McGlynn, E.A. (1995), “Quality assessment of reproductive health services". Western Journal of Medicine, 163 (3), 19-37.

- Tomes, A.E. and Ng, S.C.P. (1995), "Service quality in hospital care: the development of in- patient questionnaire," International Journal of Health Care Quality Assurance, 8 (3), 25-33.

- Berman Brown, Louise Bell, (1998) Patient-centered audit: a users' quality model, Managing Service Quality, 8 2.88-96

- Varkey, Medical Quality Management: Theory and Practice (29-40). USA: Jones and Bartlett Publishers, LLC, and American College of Medical Quality. 
Prestige International Journal of Management \& IT-Sanchayan, Vol. 8 (2), 2019, pp. 57-70, ISSN : 2277-1689 (Print), 2278 - 8441 (Online)

- Campbell, S.M., Roland, S.O., \& Buetow, S.A. (2000). Defining quality ofcare. Journal of Social Science \& Medicine, 51,1611-1625.

- Carman, J.M. (2000), Patient perceptions of service quality: combining thedimensions, Journal of Services Marketing, 14 (4), 337-352.

- Choi, K.S., Hanjoon Lee., Chankon Kim., \& Sunhee Lee. (2005). Theservice quality dimensions and patient satisfaction relationships in South Korea: comparisons across gender, age and types of service. Journal of Services Marketing, 19 (3), 140149.

- Lim, P \& Tang, N 2000, A study of patient's expectations and satisfaction in Singapore hospitals', International Journal of Health Care Quality Assurance, 13, 7, 290-299.

- Duggirala, D., Rajendran, C., \& Anantharaman, R.N. (2008). “Patient perceived dimensions of total quality service in healthcare". Benchmarking:An International Journal, 15 (5), 560-83.

- Abdul Majeed Alhashem, HabibAlquraini \& Rafiqul I Chowdhury2011,_Factors influencingpatient satisfaction in primary healthcareclinics in Kuwait', International Journal of Health Care Quality Assurance, 24, 3, 249.

- Markanday Ahuja, Seema Mahlawat \& Rana Zehra Masood 2011, Study of Service Quality Management Model: An Empirical Study of Govt/NGO'S Eye Hospitals In Haryana', Indian Journal of Commerce\& Management Studies., II, .2, .310-318.

- Kasthuri A. (2018). Challenges to Healthcare in India - The Five A's. Indian journal of community medicine : official publication of Indian Association of Preventive $\mathcal{E}$ Social Medicine, 43(3), 141-143. doi:10.4103/ijcm.IJCM_194_18

- Meijer, A., \& Bolívar, M. P. R. (2016). Governing the smart city: a review of the literature on smart urban governance. International Review of Administrative Sciences, 82(2),392-408. https:// doi.org/10.1177/0020852314564308

- Cutler DM. Rising Medical Costs Mean More Rough Times Ahead. JAMA. 2017;318(6):508-509. doi:10.1001/jama.2017.8931

- Kabene SM, Orchard C, Howard JM, Soriano MA, Leduc R. The importanceof human resources management in health care: a global context. Human ResourceKabene Health. 2006;4:20. doi:10.1186/1478-4491-4-20.

- Frenk J, Sepúlveda J, Gómez-Dantés O, Knaul F. Evidence-based health policy:three generations of reform in Mexico. Lancet. 2003;9396(362):1667-71.

- Tiwari, R., Negandhi, H., \& Zodpey, S. P. (2018). Health Management Workforce for India in 2030. Frontiers in public health, 6, 227. doi:10.3389/fpubh.2018.00227

- Belle, A., Thiagarajan, R., Soroushmehr, S. M., Navidi, F., Beard, D. A., \& Najarian, K. (2015). Big Data Analytics in Healthcare. BioMed research international, 2015, 370194. doi:10.1155/2015/370194 